\title{
Hipóteses de
}

\section{ALCIR PÉCORA}

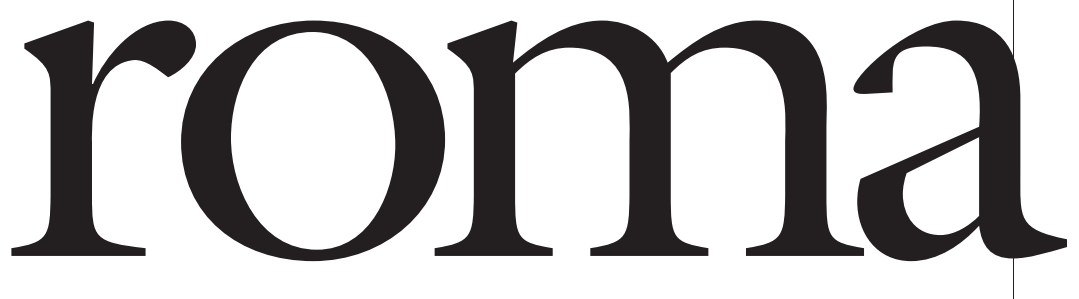

Contar a Romã, de Moacir Amâncio, é um livro de poemas intrigantes. Em seus momentos mais radicais, desafia as mais variadas e atentas estratégias de legibilidade. Para quem aceita e acha gosto numa escrita despudoramente cerebral, torna-se logo um quebra-cabeça com urgência de ser decifrado. O que também significa, como está claro para os viciados nesse tipo de jogo mental, que o principal resultado, a chave do enigma, não é algo que se possa, ou que importe exibir fora do próprio ato da decifração. O exercício de decifrar é a resposta, mais do que o decifrado. Para falar desse gosto e vício alimentado pela poesia de Moacir Amâncio, escolhi ler de perto e expor com lentidão escolar o que se passa rapidamente no curto poema que encerra o volume, construído justamente em torno do nome do fruto que lhe dá título.

\section{"A prática vermelha das romãs"}

\section{ALCIR PÉCORA é}

professor de Literatura na Unicamp e autor de Teatro do Sacramento (Edusp/Ed. da Unicamp).

Contar a Romã, de Moacir Amâncio, São Paulo, Globo, 2001.
Evidentemente, estranha o termo "prática" aplicado ao fruto. Solicita, então, duas hipóteses: primeira, a de que refira o ser do fruto como processo ou natureza em operação, isto é, que o fruto se defina como efeito de uma transformação ou de uma maneira de existir, mais do que como uma coisa perfeita e acabada em si mesma. Avançando a ponderação, pode-se traduzir "prática” por "hábito", entendido como o procedimento ou atribuição mais comum 
ou estável a operar na produção do fruto, no caso, a sua cor vermelha: o existir vermelhamente que é próprio das romãs. Antes que se organize essa primeira hipótese, em que o ser se troca em hábito ou modo, e, portanto, em que a substância se dissolve em regularidade ativa ou, no limite, em fenômeno apresentado à vista, descobre-se a segunda, surgida da acepção mais antiga do termo "prática" como "conversa" ou “discurso". Nesse caso, “falam” ou “falamse" as romãs, à imagem de um poema enumerativo de Qorpo Santo - referido numa seção anterior de Contar a Romã como uma “falação", um "pandiálogo de correspondências incongruentes" -, de que se pode dar idéia por sua última estrofe: “[ ...] Falam-se os matos, / Falam-se os ratos,/ Falam-se as flores,/ Falam-se as tigras!/ Todos se falam!”.

A reunir as duas hipóteses pode-se pensar num hábito de ser do fruto que se traduz num discurso de correspondências, cuja dominante é o vermelho, cor que tanto se dissemina por sua casca, quanto se concentra nas carnes que envolvem suas sementes. Dessa forma, simplificando o que se disse, o primeiro verso desenha a romã como um vermelho eloqüente.

\section{"distribui-se nuns súbitos cristais"}

Neste segundo verso, a operação da espécie "romã", que é também conversa em que predomina a cor vermelha, "distri- bui-se”, o que implica em proliferação, difusão. Produz-se aqui algo semelhante ao que anuncia um outro poema do volume, cujo primeiro verso justamente apostrofa: "Polivermelha romã". Tal proliferação, contudo, não é a do espalhar-se somente: ela se faz por meio de "súbitos cristais", pela multiplicação de unidades discretas, o que imediatamente solicita a lembrança das sementes da romã, miúdas e múltiplas. Ao propor ainda o análogo dos “súbitos cristais", a multiplicidade se entende também como brilho repentino, relampejar, isto é, como operação da cor percorrida por um clarão elétrico. $\mathrm{O}$ traço nervoso, ou explosivo da descrição está manifesto em vários outros poemas do volume; por exemplo: “O relâmpago mostra/ esta eletricidade,/ uma flor em ação". No entanto, tal como se lê, trata-se de um clarão que percorre a multiplicidade no pequeno, de uma cena que prolifera ou acumula no detalhe.

Há outro aspecto a considerar: se são “cristais", o brilhoé também precioso, elevado, embora evidentemente não sublime, pois descrito a partir da miudeza. Retomando as hipóteses levantadas no primeiro verso, teríamos de dizer que se descreve a maquinaria ou operação do fruto a distribuir seu vermelho pelos vários grãos, e também que a eloquiência própria da romã é a de comunicar-se, ou comunicar a vermelhidão que preside sua máquina, por meio de uma espécie de corrente elétrica a percorrer as muitas sementes vermelhas. 
Há uma novidade, porém, nesse segundo verso, introduzida tanto pela elevação suposta em "cristais" quanto pela contraposição deles a "romã". O fruto, desde os cânticos de Salomão, ou em definitivo depois deles, pode significar tudo, menos coisas ou atos isentos do desejo em seu viés mais marcadamente erótico: “Os teus lábios são como uma fita de escarlate; e o teu falar é doce. Assim como é o vermelho da romã partida, assim são as tuas faces, sem falar no que está escondido dentro" $(4,3)$; "As tuas plantas formam um jardim de delícias de toda a qualidade de romãs, de frutos de cipre e de nardo" $(4,13)$.

Ademais, articular-se o vermelho ao cristal, no âmbito de análogos de um fruto como a romã, solicita imediatamente a tradição poética do retrato galante ou erótico. Não é preciso insistir nisso, mas convém notar que, nessa tradição, quando "romãs" são a pintura do rubor das faces ou dos lábios vermelhos, "cristais" referem, em contrastante beleza, a brancura e o brilho dos dentes. Tal constatação descobre o equívoco como principal figura a sustentar o dístico inicial do poema. Isso quer dizer que ele desempenha seus sentidos numa dupla mão, irredutível: descreve-se, de um lado, o avermelhado das romãs que, tingindo a casca, cristaliza-se nos grãos brilhantes que recobrem as sementes; de outro, o deslocamento dos lábios vermelhos a descobrir o brilho dos dentes. Ambas as pontas do equívoco são amarradas pela noção de discurso, de conversa existente como operação visível da natureza no modo de ser do fruto, ou como insinuação já factível no movimento da boca que se abre.

\section{"entalhes soletrados tantas letras"}

A predominância da idéia de discurso a atar o equívoco produzido pelos dois versos anteriores explicita-se neste terceiro, desenhado só. Não se perde nenhum dos planos descritivos em jogo: "entalhes soletrados" - imagem que se reitera em "tantas letras" e prolifera como eco e aliteração no conjunto do verso -, são os grãos das romãs encravados nas cavidades formadas pelas películas internas, como podem ser os dentes entrevistos no movimento da boca. Nos dois casos, contudo, o discurso enreda ou absorve as descrições. Na via interpretativa em que a romã é fruto, descreve-se sobretudo o discurso inscrito nele, que pode ser primordial ou ter fundamento metafísico, mas em que sobretudo conta a comunicação que efetivamente produz, eletrizando a sua presença face a quem o vê. Na linha de ponderação em que a romã é metáfora de lábios - não exclusivamente os da face, como os Cânticos não deixam esquecer -, o seu movimento manifesta eloquiências múltiplas. Ou seja, enquanto equívoco de fruto e de lábios, a romã é metáfora que descreve a matéria impregnada de discurso, ou, enfim, a própria metáfora dentro da coisa. De outra maneira: ao reconhecer como discurso o movimento material que está no fruto e nos lábios, reconhece-se igualmente que matéria e fala perfazem uma espécie de lei de imanência recíproca.

\section{"quanto podem à flor da boca os olhos"}

O mais imediato deste verso final traz à luz a "boca" insinuada desde o princípio. Numa ordem direta, poderíamos reconstruir a sua relação com o resto do poema por meio da seguinte proporção: são tantas as "letras" ou os discursos pronunciados pelos lábios quanto aquele que os vê é capaz de ler neles. Ou, mais sinteticamente: tanto diz a boca, quanto o olho a lê. A matéria que, como se viu, discursava em seus movimentos próprios, agora se ancora no olhar que a contempla. Se a matéria fala, quem a anima é o seu leitor. O discurso erótico com que a matéria fala é, sobretudo, invenção ou potência do observador. Se a matéria discursa, a sua fala não repousa em si mesma, mas na possibilidade de atribuir-lhe gramática e interlocução. É à atribuição, à leitura, à interlocução que se 
dá a prerrogativa poética de fundar as letras nas coisas, de ler ou entender coisas como linguagens. Nessa direção, o poema afirma o seu poder demiúrgico, modelador de coisas e formas, e o seu interesse principal reside na radicalidade, e mesmo talvez na violência com que as submete ao seu uso metafórico ou poético.

Mas o que significa precisamente, no poema, essa submissão da matéria à poesia? Em primeiro lugar, significa reduzi-la a aspectos visíveis. Seja na mão semântica em que a romã é fruto, seja na que é boca, trata-se de descrever, em ambas, o que se dá a ver: o vermelho primeiro, depois o alvo, brilhante e múltiplo, e, enfim, o reconhecimento das descrições como uma dupla literalidade que apenas se anima pelo gesto do criador. E que gesto é esse último, transformador e animador? Justamente o gesto que cruza essa dupla literalidade existente no equívoco, que produz um esforço de troca metafórica nas duas cenas físicas do olhar. Quer dizer, após desenvolver com habilidade duas possibilidades descritivas plausíveis ao longo dos versos, o que o poema faz, ao final, é uma intersecção abrupta de ambas num conceito único que se exibe como artifício criador. Assim, o fruto e os lábios se reúnem na "flor da boca", concetto engenhoso a estabelecer correspondência entre dois objetos extremos. O que acompanhávamos como coisas dá-se agora diante de nós como golpe de vista, como foco, como enquadramento, como montagem discursiva.

Antes de encerrar este exercício escolar de leitura do poema, convém trazer à tona certos elementos sintáticos e rítmicos. Que são decassílabos heróicos é difícil não ler, o que ainda uma vez reforça a relevância da tradição poética para o poema; mas o que é especialmente interessante aqui é que todos os versos são nitidamente bimembres, a não ser o último, que admite também uma divisão tripartite: “quanto podem/à flor da boca/ os olhos". O primeiro efeito disso evidentemente é retardar o desfecho, tornar mais lento o enunciado do verso conclusivo, no que é bem-sucedido. Mas essa quebra de regularidade bipolar, para ser produzida, também inverte a posição que seria mais comum entre “à flor da boca e os olhos", o que gera um novo equívoco justamente no verso derradeiro. Agora, os olhos são aquilo que vê a flor, como já se alertou, mas são também o que está nela, de tal modo que a vista, nesta hipótese, dá-se de dentro da romã para fora dela. Neste ponto, “olhos" não nomeiam o instrumento conceitual externo que permite juntar na "flor da boca" os frutos mais os lábios, mas simum novo desdobramento ou proliferação interna às duas literalidades em jogo - "olhos" são, nesse caso, os grãos vivos da romã, bem como os brilhos (dentados?) na boca. Essa mesma possibilidade, de forma ainda mais nítida, aparece em outro poema dolivro, que também toma a romã como tema: "uns olhos em coleção,/ olhos para serem vistos,/ favos de papel lavrados/ em tanino $[\ldots]$ ".

Em termos da interpretação mais geral, a manutenção do equívoco, sem síntese engenhosa final, relativiza o aspecto demiúrgico referido anteriormente, isto é, o poema celebra menos a capacidade de submissão das coisas pelas palavras, do que, ainda uma vez, a correspondência imanente entre tudo o que existe. No primeiro caso, quando os olhos concebem de fora a "flor da boca", celebra-se principalmente o artifício da sua invenção ou o triunfo da síntese sobre as coisas distintas que lhe fornecem matéria; no segundo, agora referido, quando os olhos estão na flor que nos olha, o que se prescreve ou ressalta é uma linguagem fundada numa natureza que ainda parece guardar uma dinâmica própria, plena de ressonâncias e de razões ocultas. Sem síntese final, pois, o que mais lhe toca que produzir essa espécie de diálogo de objetos incongruentes? 